\title{
Variation in photosynthetic rates among individual cells of a marine dinoflagellate
}

\author{
Elizabeth G. Boulding \& Trevor Platt
}

Marine Ecology Laboratory, Bedford Institute of Oceanography, Box 1006, Dartmouth, Nova Scotia B2X 4A2, Canada

\begin{abstract}
Rates of photosynthesis for individual cells from a field population of the dinoflagellate Ceratium tripos were measured by incubating them in situ with $\mathrm{NaH}^{14} \mathrm{CO}_{3}$ then assaying them, 1 cell per scintillation vial. The mean rate per cell was a maximum of 0.51 to $0.71 \mathrm{ng} \mathrm{C}$ cell $^{-1} \mathrm{~h}^{-1}$ (estimated doubling time 5.9 to $4.2 \mathrm{~d}$ ) at the surface and an order of magnitude less at greater depths or on cloudy days. For each of 4 sampling dates the estimate of carbon specific growth obtained for $C$. tripos using this single cell assay was correlated significantly with the estimate obtained for the entire phytoplankton community using conventional filter techniques. We used cultures of the related Ceratium longipes to prove the single cell assay against a direct measurement (absolute increase in carbon per cell) and obtained agreement within $5 \%$. Individual cells from the same water samples differed in their absolute rates of tracer uptake, a previously unknown dimension of population structure in phytoplankton. Factors that may contribute to this variation are discussed.
\end{abstract}

The reliability of conventional ${ }^{14} \mathrm{C}$ estimates of phytoplankton production in the sea continues to be disputed (Williams et al. 1983, Smith et al. 1984, Jenkins \& Goldman 1985). Interpretation of the tracer uptake is equivocal because the experiments are done in entire microbial communities, including heterotrophs as well as autotrophs (Peterson 1980). We have overcome the ambiguity by measuring the assimilation of tracer in individual phytoplankton cells and by verifying the result against a direct measurement that is independent of both tracer methodology and food web structure.

Of the techniques available for estimating the production of individual phytoplankton species, only the single cell ${ }^{14} \mathrm{C}$ assay (Rivkin \& Seliger 1981) is easy to learn, requires little equipment and can be used for most phytoplankton species $(>15 \mu \mathrm{m})$. The results from grain density autoradiography may not be quantitative and the technique of track autoradiography is difficult to master (Knoechel \& Kalff 1976). Swift \& Durbin's (1972) technique of estimating in situ division rates

(C) Inter-Research/Printed in F. R. Germany seems applicable only for dinoflagellates with synchronized division periods and gives average growth rates (Rivkin et al. 1984) which are not useful if the relation between carbon fixation and light is of primary interest. Post-incubation sorting of ${ }^{14} \mathrm{C}$-labelled cells can be done automatically with a flow cytometer but the procedure requires considerable capital outlay and operator training, is restricted in the size range of cells it can handle (approximately 1 to $50 \mu \mathrm{m}$ ) and cannot separate species if they are of the same size and have the same pigment complement (W. K. W. Li, pers. comm.).

To measure the uptake of ${ }^{14} \mathrm{C}$ we used a modification of the method previously described by Rivkin \& Seliger (1981). The principal changes were (1) individual cells were picked hydraulically using a drawn-glass capillary tube (Throndsen 1978) in a micromanipulator; (2) the washed cells were acidified directly in the scintillation vials to remove residual inorganic ${ }^{14} \mathrm{C}_{i}$ and (3) the radioactivity of individual cells was assayed, 1 cell per scintillation vial, until the $95 \%$ confidence limits were within $5 \%$ of the mean counts per minute.

The procedure was tested on a culture population of Ceratium longipes maintained in F/10 medium (Guillard 1975 ) at $15^{\circ} \mathrm{C}$ under $400 \mu \mathrm{Em}^{-2} \mathrm{~s}^{-1}$ with a $14: 10$ light:dark cycle. A subsample of the culture was incubated under the same conditions for the first $7 \mathrm{~h}$ of the light period with $\mathrm{NaH}^{14} \mathrm{CO}_{3}$ at a final activity of $1.0 \mu \mathrm{Ci}$ $\mathrm{cm}^{-3}$. Some 100 cells were isolated for radioactive assay and the results used to calculate average uptake rates $\left(2.27 \mathrm{ng} \mathrm{C}\right.$ cell ${ }^{-1} \mathrm{~d}^{-1}$, standard deviation, $\mathrm{s}=$ 0.041 ; daily rate $=$ twice $7 \mathrm{~h}$ rate). Three aliquots of the main culture containing an estimated 46,000 cells were removed at the beginning and the end of the light period and filtered onto silver filters with a pore size of $0.8 \mu \mathrm{m}$. The carbon retained on the filters was measured on a Perkin-Elmer Elemental Analyser (model 240). The change in the amount of carbon per cell was 
$2.16 \mathrm{ng} \mathrm{C}$ cell ${ }^{-1} \mathrm{~d}^{-1}(\mathrm{~s}=0.356)$, which was within $5 \%$ of the single cell estimate.

The species chosen for our field experiments was Ceratium tripos, a large dinoflagellate commonly occurring in blooms of extremely low species diversity (Elbrächter 1973, Falkowski et al. 1980). These blooms can result in anoxic conditions which cause extensive fish and shellfish kills (Falkowski et al. 1980) and are common in near-shore areas on both sides of the Atlantic ocean (Elbrächter 1973) including Bedford Basin $\left(44^{\circ} 32^{\prime} \mathrm{N}, 63^{\circ} 39^{\prime} \mathrm{W}\right)$. During November 1984, the phytoplankton was sampled on 4 occasions from 3 depths $(0.5,5.0$, and either 10.0 or $15.0 \mathrm{~m})$ and incubated in situ for 2 to $4 \mathrm{~h}$ with $\mathrm{NaH}^{14} \mathrm{CO}_{3}$ at a final activity of $1.0 \mu \mathrm{Ci} \mathrm{cm}^{-3}$. Two light bottles (volume $=$ $250 \mathrm{~cm}^{3}$ ) and 1 dark bottle were used at each depth. Temperature and salinity were measured with a Guildline SCTD, and water samples for the determination of nutrients, chlorophyll, and carbon were collected in Niskin bottles. At the end of the incubation period three $25 \mathrm{~cm}^{3}$ samples were taken from each bottle and filtered through Whatman GF/F filters. These filters were fumed over concentrated $\mathrm{HCl}$ then counted with a Beckman 3100 liquid scintillation counter. Dark respiration was corrected for by subtracting the mean cpm for the filters from the appropriate dark bottle. The remainder of the sample was filtered through $76 \mu \mathrm{m}$ Nitex, rinsed well with filtered seawater, backwashed and resuspended. Some 25 cells were then processed using the single cell procedure described above.

For individual cells radiocarbon was assimilated to a mean activity of 1.2 to $74.0 \mathrm{dpm}$ above background, depending on light intensity (incubation depth). Estimates of total phytoplankton carbon per $\mathrm{m}^{3}$ were obtained from a regression of total particulate carbon on chlorophyll (slope $=62.6, \mathrm{r}^{2}=0.681, \mathrm{p}<0.01$, $\mathrm{N}=9$ ). A mean value of $34.7 \mathrm{ng} \mathrm{C}$ cell ${ }^{-1}$ was obtained for an average Ceratium tripos by picking out 500 cells, filtering them onto a precombusted GF/F filter, and analysing this on the elemental analyser as above. For each of the 4 sampling dates the estimate of carbon specific growth rate $\left(\frac{\triangle \mathrm{C}}{\Delta \mathrm{t}} \cdot \frac{1}{\mathrm{C}}\right)$ obtained for $C$. tripos using the single cell procedure correlated significantly with that obtained for the entire phytoplankton community sampled from the same light bottle using the conventional GF/F filter procedure (Fig. 1e to h). The ratio of the single cell estimate to the conventional filter estimate was 0.76 at the beginning of November but had decreased to 0.2 by the end of November perhaps because faster growing phytoplankton became more abundant.

Downwelling irradiance at depth was calculated from surface light levels attenuated by the extinction coefficient. Surface light levels were calculated by multiplying the values obtained from the KIPP CM6 pyranometer located at Halifax Citadel $\left(44^{\circ} 39^{\prime} \mathrm{N}\right.$, $63^{\circ} 35^{\prime} \mathrm{W}$ ) by 0.45 to obtain the photosynthetically active radiation (P.A.R.) that penetrated the air-water interface. The extinction coefficient was measured with a LICOR LI-185A quantum meter.

The mean productivity per cell decreased with the decrease in downwelling irradiance at greater depths for all 4 sampling dates (Fig. 1a to d). It is inappropriate to make a composite plot of all the data because the time between sampling dates (minimum of $1 \mathrm{wk}$ ) is too long. The maximum rates of photosynthesis obtained for Ceratium tripos, 0.51 to $0.71 \mathrm{ng} \mathrm{C} \mathrm{Cell}^{-1} \mathrm{~h}^{-1}$ (Fig. 1a to d) at approximately $10^{\circ} \mathrm{C}$, give doubling times $\left(\frac{\Delta \mathrm{t}}{\triangle \mathrm{C}} \cdot \mathrm{C} \cdot \ln 2\right)$ of 5.9 to $4.2 \mathrm{~d}$, assuming a daylength of $8 \mathrm{~h}$ and not correcting for dark respiration (which was not distinguishable from background even when 5 cells were assayed together). The rates of photosynthesis at greater depths were of course lower, 0.30 to $0.049 \mathrm{ng} \mathrm{C}$ cell $^{-1} \mathrm{~h}^{-1}$ at $5.0 \mathrm{~m}$ (Fig. $1 \mathrm{a}$ to $\mathrm{d}$ ), and gave doubling times of 10 to $61 \mathrm{~d}$.

Given that nutrients were always measurable (nitrate $>1.5 \mathrm{mg}$-at $\mathrm{m}^{-3}$ ), but that average light levels during incubation periods were relatively low, these estimates agree with those previously published for Ceratium tripos. Data from the conventional filter technique, carbon estimates and direct cell counts suggested a doubling time of 20 to $30 \mathrm{~d}$ for large $C$. tripos (25 ng C cell ${ }^{-1}$ ) during a bloom in the New York Bight (Falkowski et al. 1980). And doubling times estimated by observing the maximum frequency of dividing cells in Kiel Bay gave values ranging from $2.5 \mathrm{~d}$ at $16^{\circ} \mathrm{C}$ to 22 days at $10^{\circ} \mathrm{C}$ (Elbrächter 1973). C. tripos from Kiel Bay were observed to be capable of surviving up to $41 \mathrm{~d}$ without dividing (Elbrächter 1973), so even the low rates we obtained for the cells from $10.0 \mathrm{~m}$ may enable survival until the cells are again higher in the euphotic zone.

Even though any 2 replicate light bottles had very similar means (Fig. 1 \& 2) there was considerable variation among cells within any 1 bottle, with productivity of some cells being twice that of others (Fig. 2). The coefficients of variation $(\mathrm{s} / \mathrm{x})$ range from 28.7 to $73 \%$ ( $\mathrm{N}=25$ cells) for the Ceratium tripos incubated in the field and from 28.8 to $39.7 \%$ ( $N=100$ cells) for the $C$. longipes incubated in the laboratory. Less than $1.5 \%$ of the variance in the means is attributable to the 2 sigma counting error of $5 \%\left(\left[(\mathrm{~N}-1) \mathrm{s}^{2}+\mathrm{Nx}^{2}\right] /\right.$ [1600 $\mathrm{N}^{2} \mathrm{~s}^{2}$ ]). The 3 most probable causes of this variation are: (1) variation in cell age, (2) variation in cell size, and (3) variation in the cells' environmental history.

Variation in productivity associated with cell age is confounded with variation associated with cell size 
Fig. 1. Primary production in Bedford Basin on 4 sampling dates from in situ incubations at

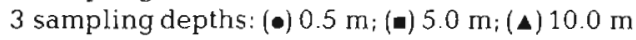
or (x) $15.0 \mathrm{~m}$. (a to d) Productivity of Ceratium tripos as a function of light intensity. Each point represents the mean of some 25 cells isolated from the same incubation bottle (see text). (e to h) Correlation between the estimate of carbon specific growth rate $\left(\frac{1}{C} \quad \frac{\Delta C}{\Delta t}\right)$ obtained for Ceratium tripos and the estimate obtained for the entire phytoplankton community from the same incubation bottle (see text). The correlations between the 2 estimates are: $0.976,0.995$, $0.978,0.994$ for Nov $1,13,20, \& 29$, respectively
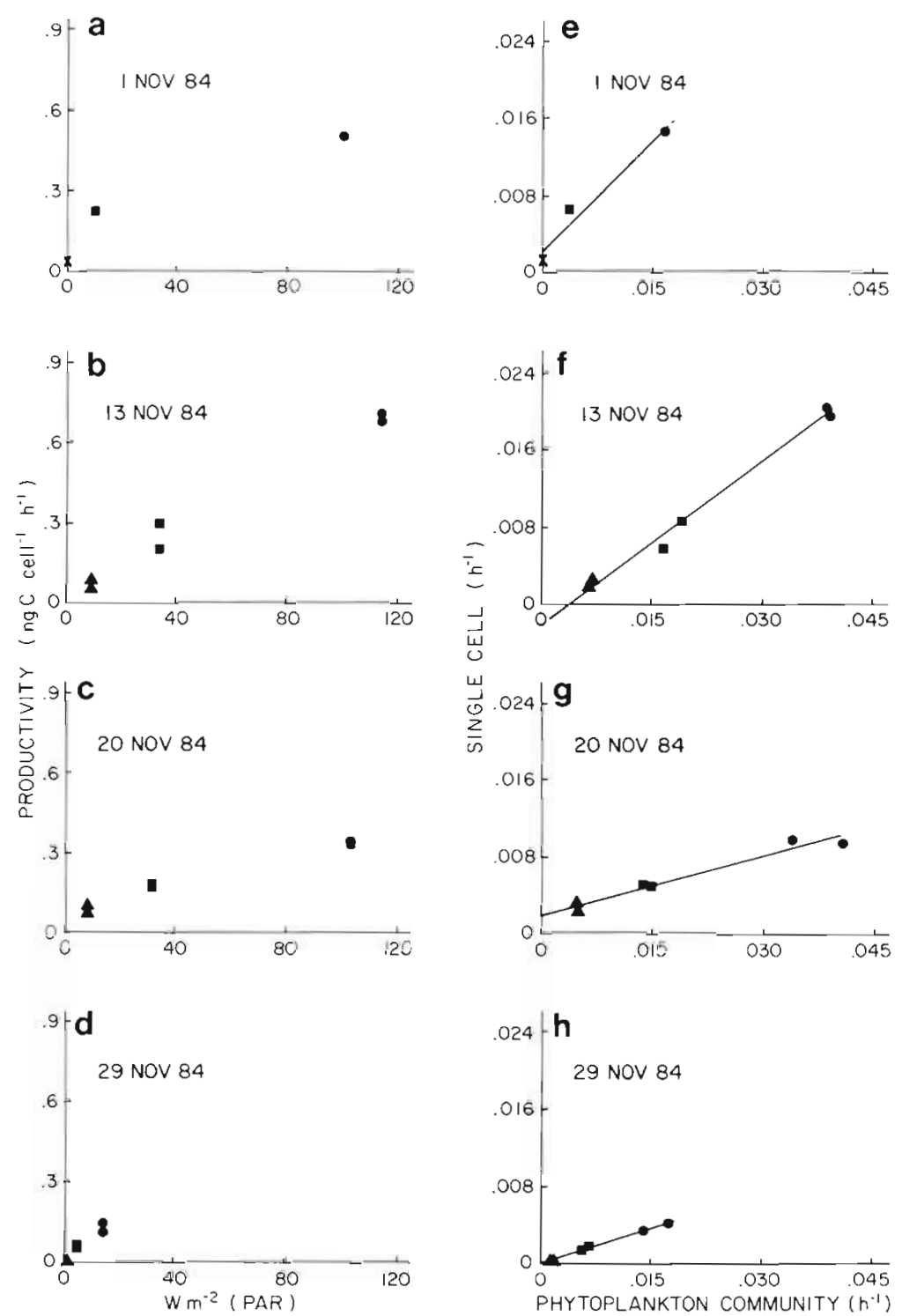

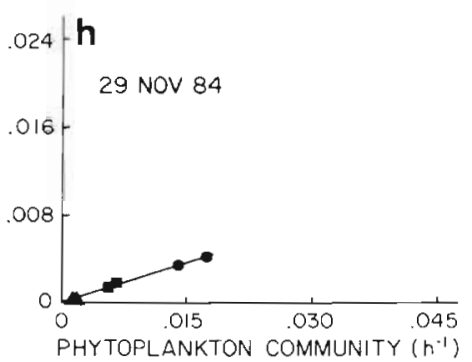

since recently-divided cells are also smaller. Ceratium longipes and $C$. tripos divide synchronously during the dark period. Recently divided cells can be identified by the relative length of their apical horn to their antapical horns. We used the single cell uptake procedure to measure the average uptake over $6 \mathrm{~h}$ of recently divided $C$. longipes and compared this with that of 2 to $3 \mathrm{~d}$ old cells from the same culture flask. The mean production per cell was significantly higher for the older cells (Mann-Whitney $U, p<0.001$ ). The lower production of the recently-divided cells does not result from an inhibition of photosynthesis by the division process. In a subsequent experiment involving three $1 \mathrm{~h}$ incubations begun at 06:00 $\mathrm{h}$ (the beginning of the light period), $08: 00 \mathrm{~h}$, and $14: 00 \mathrm{~h}$, the production of the recently-divided cells was always significantly less than that of older cells from the same culture (ANOVA, $\mathrm{p}<0.0001$ ) but even at 06:00 $\mathrm{h}$ the recently-divided cells took up ${ }^{14} \mathrm{C}$ at $79 \%$ the rate of the older cells. In our field experiments we used a large mesh size and avoided picking-out recently divided $C$. tripos. Variance in cell size may be important however: we found cell body diameters to vary from 60 to $75 \mu \mathrm{m}$ from the same water sample.

Variation in the cells' environmental history occurs even among cells collected in the same water sample because of the stochastic nature of local turbulent mixing, and it can lead to variation in physiological properties (Lewis et al. 1984).

An additional contributing factor could be genetic differences among cells. The importance of this could be assessed by initiating cultures with single cells isolated from natural populations, growing at least 2 replicate flasks of each of these original cultures 

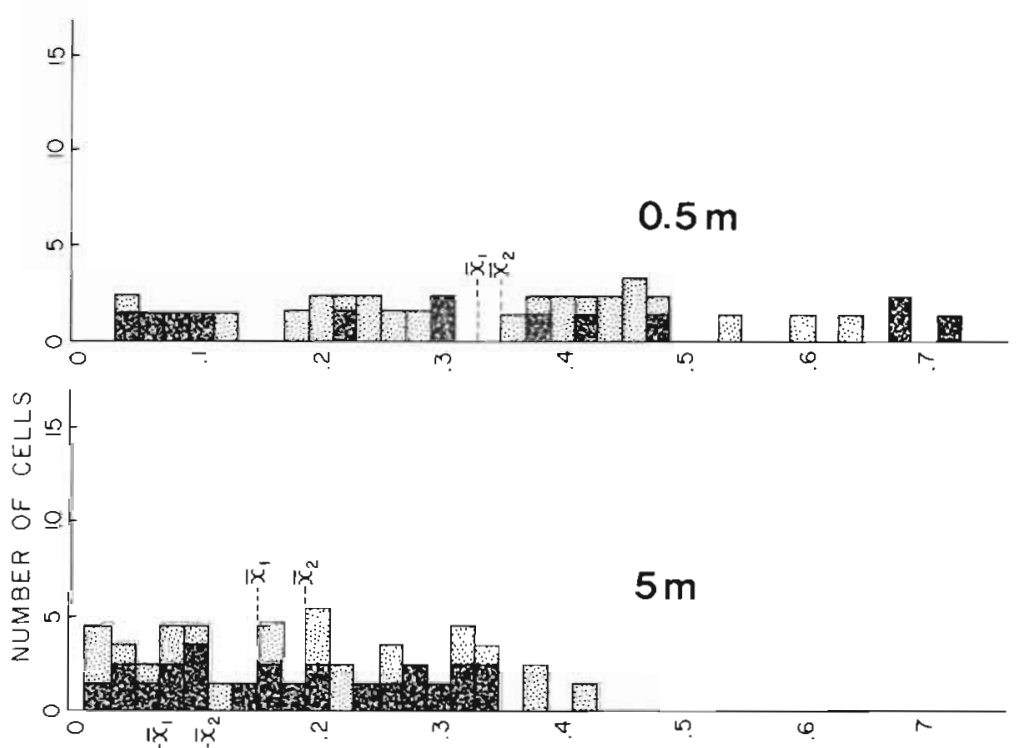

Fig. 2. Ceratium tripos. Distribution in productivity of individual cells. Data from November 20,1984 . Data from the 2 replicate bottles at the same depth are combined into the same histogram but the mean is shown for each bottle. All 3 histograms are plotted at the same scale which might give the illusion that the data for $10.0 \mathrm{~m}$ are less variable than the data for $0.5 \mathrm{~m}$. Comparison of the coefficients of variation $(5 \sqrt{x})$ (0.5 m: 73.4, 44.8; $5.0 \mathrm{~m}: 61.2,70.0 ; 10.0 \mathrm{~m}: 66.1$, $33.7)$ shows that the variance in productivity is roughly the same at all 3 depths, as it was on the other sampling dates

under the same environmental conditions for several generations, then using ANOVA to compare the productivity within and between the different cell lines.

The variation that we report here in assimilation rates among individual cells cannot be seen unless cells are assayed 1 cell per vial and incubated under conditions that result in the uptake of at least $10 \mathrm{dpm}$ above background. Our procedure has the power to detect differences both between species and within populations, both features of merit for investigation of phytoplankton ecology in an evolutionary context. By avoiding complications that arise from food-web structure, we have shown that the ${ }^{14} \mathrm{C}$ method is able to give an estimate of the rate of carbon fixation in phytoplankton that is both accurate and precise.

Acknowledgements. We are grateful to S. Angeledis for supplying cultures of Ceratium longipes and for other assistance with this study. We also thank T. Hay, B. Irwin, and D. Sharp. Drs. W. Li and W. G. Harrison commented on the manuscript.

\section{LITERATURE CITED}

Elbrächter, M. (1973). Population dynamics of Ceratium in coastal waters of the Kiel Bay, Oikos 15 (suppl.): 43-48

Falkowski, P. G., Hopkins, T. S., Walsh, J. J. (1980). An analy- sis of factors affecting oxygen depletion in the New York Bight. J. mar. Res. 38: 479-506

Guillard, R. R. L. (1975). Culture of phytoplankton for feeding marine invertebrates. In: Smith, W. L., Charley, U. H. (ed.) Culture of marine invertebrate animals. Plenum, New York, p. 26-60

Jenkins, W. J., Goldman, J. C. (1985). Seasonal oxygen cycling and primary production in the Sargasso Sea. J. mar. Res. 43: 465-491

Knoechel, R., Kalff, J. (1976). The applicability of grain density autoradiography to the quantitative determination of algal species production: A critique. Limnol. Oceanogr. 21: $583-590$

Lewis, M. R., Horne, E. P. W., Cullen, J. J., Oakey, N. S., Platt, T. (1984). Turbulent motions may control phytoplankton photosynthesis in the upper ocean. Nature, Lond. 311: $49-50$

Peterson, B. J. (1980). Aquatic primary productivity and the ${ }^{14} \mathrm{C}-\mathrm{CO}_{2}$ method: a history of the productivity problem. A. Rev. Ecol. Syst. 11: 364-385

Rivkin, R. B., Seliger, H. H. (1981). Liquid scintillation counting for ${ }^{14} \mathrm{C}$ uptake of single algal cells isolated from natural samples. Limnol. Oceanogr. 26: 780-785

Rivkin, R. B., Swift, E., Biggley, W. H., Voytek, M. A. (1984). Growth and carbon uptake by natural populations of oceanic dinoflagellates Pyrocystis noctiluca and Pytocystis fusiformis. Deep Sea Res. 31: 353-367

Smith, R. E. H., Geider, R. J., Platt, T. (1984). Microplankton productivity in the oligotrophic ocean. Nature, Lond. 311 252-254 
Swift, E., Durbin, E. G. (1972). The phased division and cytological characteristics of Pyrocystis spp. can be used to estimate doubling times of their populations in the sea. Deep Sea Res. 19: 189-198

Throndsen, J. (1978). Isolation of single cells. In: Sournia, A (ed.) Phytoplankton manual. UNESCO, Paris, p. 132-135
Williams, P. J. LeB., Heinemann, K. R., Marra, J., Purdie, D. A. (1983). Comparison of ${ }^{14} \mathrm{C}$ and $\mathrm{O}_{2}$ measurements of phytoplankton production in oligotrophic waters. Nature, Lond. 305: 49-50

Accepted for printing on November 28, 1985 